\title{
Realities and Strategies in Managing North Korea's Nuclear Challenge
}

\author{
Chung Kyung- \\ young
}

\begin{abstract}
The nuclear program is arguably Kim Jong-un's strategic fantasy and core asset for breaking the status quo in order to achieve a unified Korea. To cope with North Korea's grave nuclear and missile threats, the Terminal High Altitude Area Defense (THAAD) system needs to be deployed in South Korea for deterrence by denial. In the meantime, the United Nations Security Council (UNSC) should not exclude the military option in the event of any further nuclear test and Intercontinental Ballistic Missile (ICBM) launch experiment by North Korea. The U.S. government should consider redeploying tactical nuclear warheads to South Korea in order to make the extended deterrence more effective. The South Korean government should make it clear that the Republic of Korea (ROK) does not seek to join, nor will it be incorporated into, the U.S.-led missile defense system. The United States and China should cooperate
\end{abstract}

Chung Kyung-young is Adjunct Professor at the Graduate School of International Studies, Hanyang University. His mailing address is: Korean Studies Department, Graduate School, Hanyang University, 222 Wangshimni-ro Seongdong-gu, Seoul, South Korea 04763. He can also be contacted at chungky@hanyang.ac.kr.

The views expressed in this article are solely those of the author and do not reflect the position of this journal or any institution whatsoever.

(C) 2016 World Century Publishing Corporation and Shanghai Institutes for International Studies China Quarterly of International Strategic Studies, Vol. 2, No. 4, 465-484

DOI: $10.1142 / \mathrm{S} 2377740016500299$ 
with South Korea to take the lead in achieving a norm-oriented, nuclearfree, and unified Korea. In particular, ROK-U.S.-China strategic cooperation is essential to preventing any potential nuclear warfare and maintaining peace and stability on the Korean Peninsula. South Korea, the United States and China should propose restructured negotiations on important issues that provide genuine incentives for Pyongyang, culminating in complete and verifiable denuclearization and a treaty that will end the tensions on the Peninsula. In addition, the trilateral cooperation needs to adopt a more proactive engagement policy to facilitate North Korea's lasting transformation.

Keywords: North Korea's nuclear program; Terminal High Altitude Area Defense (THAAD); ROK-U.S.-China cooperation; massive retaliation; nonnuclear and unified Korea.

On the 68th anniversary of the founding of the Democratic People's Republic of Korea (DPRK) on September 9, 2016, North Korea carried out a nuclear warhead explosion test as the final stage of its nuclear arsenal development. From early January to late September, North Korea has conducted over twenty missile launch experiments, including Scud B and Scud C-ER, Rodong and Musudan missiles, an intercontinental ballistic missile (ICBM) engine test, and a submarine-launched ballistic missile (SLBM) test, in order to ensure the diversification of delivery systems for nuclear warheads. It is estimated that North Korea will eventually possess nuclear warheads equipped with missile systems with offensive capabilities. As a de facto nuclear state, North Korea has tremendous impacts on the military balance on the Korean Peninsula, and can be a game changer in Northeast Asia. Due to Kim Jong-un's willingness and capability to launch nuclear surprise attacks, the Republic of Korea (ROK) is facing serious security threats to national survival and people's lives. It is imperative that the ROK take decisive actions against the imminent catastrophe by deploying self-defense systems and a preemptive strike strategy.

Meanwhile, the South Korean and U.S. military authorities announced on July 8, 2016 that the U.S. Terminal High Altitude Area defense (THAAD) system would be deployed to South Korea by late 2017 in accordance with the self-defense right, to cope with North Korea's accelerating nuclear missile programs. The southeast area on the Peninsula was designated as THAAD's location. The official decision has spurred furious domestic and 
international protests. China and Russia vehemently oppose the deployment, concerned that it may undermine their national security and tilt the regional balance of power.

The complexity of imminent threats from North Korean nuclear missile offensive capabilities, as well as domestic and foreign challenges related to THAAD deployment, should spur ROK-U.S.-China strategic cooperation, so as to proactively manage the threat posed by North Korea's nuclear and missile programs. Security experts and policy-makers of the three countries should conduct comprehensive security assessments of the Kim Jong-un regime's intransigence in the face of crippling sanctions and increasing diplomatic isolation. If we fail to fully evaluate North Korea's intention and capabilities, calamities will very likely fall on the Korean Peninsula, and take a heavy toll on regional and global peace.

This article first analyzes North Korea's nuclear policy and military strategy for unification. It then explores the necessity of deploying THAAD in South Korea as well as major conflicting views on the deployment. The fourth section discusses China's strategic miscalculations in North Korea's nuclear issue. Finally, the article proposes some general strategies and concrete policies to cope with North Korea's nuclear challenge.

\section{North Korea's Nuclear Policy and Military Strategy for Unification}

It is generally believed that the near-term objective of North Korea's nuclear and missile policy is to achieve the miniaturization of nuclear warheads, acquire reentry technologies for its ballistic missiles, and then secure the status of a nuclear state like India and Pakistan. And its mid- to long-term objective may be to seek the lifting of economic sanctions against it and other economic rewards while reducing a certain number of nuclear warheads under the pretext of non-proliferation of weapons of mass destruction (WMD), but keeping the remaining nuclear arsenal in a clandestine manner. It may also seek to drive U.S. forces out of the Peninsula by signing a peace treaty with South Korea. With these objectives, North Korea's strategy is "to build a strong, prosperous country as the immediate goal in the northern part of the Republic and carry out revolutionary tasks of national liberation and democracy at the national level; and its final goal is to realize the autonomy of mass people by actualizing Kim Il-sungism and 
Kim Jong-ilism in the whole society," ${ }^{1}$ which explains the revision of the preamble to the regulation for Worker Party of Korea (WPK) on April 11, 2012.

Reportedly, Kim Jong-un approved a "Seven-Day War Plan" at the extended conference of the WPK Central Military Commission on August 25, 2012: the first phase is surprise attacks with nuclear missiles; the second phase is total war; the third phase is total attacks with asymmetric combat power; the fourth phase is special operations in the rear; and the final step is conquering the whole Peninsula. ${ }^{2}$ Based on this plan, North Korea's nuclear strategy has been developed as a core asset for waging a unification war. In February 2014, North Korea upgraded its nuclear forces from Strategic Rocket Command to Strategic Forces Command and settled for surprise attack doctrines. On May 7, 2016, the WPK Congress proclaimed North Korea to be a perpetual nuclear state, revealing itself from the revision of the Worker Party Regulation. It is estimated that North Korea now possesses 30 nuclear warheads, and will be able to develop approximately 50 nuclear warheads by 2020 (Table 1). After the five nuclear tests in the past decade, and with its long pursuit of miniaturizing and multiplexing nuclear explosives, North Korea forces may have been equipped with large caliber howitzers, multiple launcher systems, as well as Scud and Rodong missiles.

Since the end of the Korean War in the 1950s, North Korea has never stopped striving for the unification of the Korean Peninsula by military approaches. Kim Il-sung's military strategy was based on a combination of modern war and revolutionary war guidelines, integrating the Soviet Union's military strategic thought that emphasizes in-depth maneuvers by speed and shock, and Mao Zedong's tactic of people's war and guerrilla warfare, with its Juche (self-reliance) strategy derived from the anti-Japanese war and later Korean War experience. In comparison, his successor Kim Jong-il's military strategy was largely shaped by the impacts of the Iraq War and Afghanistan War. Worrying about a potential attack from the United

${ }^{1}$ The pillars of a strong and prosperous nation are political, military, and economic capabilities. In the Juche (self-reliance) ideology and "military-first" policy, it is believed that North Korea has already become a great military power as a nuclear state that can fight against the United States. In accordance with economic construction in parallel with nuclear armament, when conditions are met, North Korea would occupy the metropolitan area of Seoul by nuclear and missile preemptive strikes, then it will become a great economic power.

2“Kim Jong-un Approved Seven-Day War Plan,” Joongang Ilbo, January 18, 2015. 
Table 1. North Korea's Nuclear Warheads in Possession.

\begin{tabular}{|c|c|c|c|c|}
\hline \multirow[b]{2}{*}{ Classification } & \multicolumn{2}{|r|}{2016} & \multicolumn{2}{|r|}{2020} \\
\hline & Plutonium & Enriched Uranium & Plutonium & Enriched Uranium \\
\hline Possession & $12-38 \mathrm{~kg}$ & $120-240 \mathrm{~kg}$ & $6-28 \mathrm{~kg}$ & $7-64 \mathrm{~kg}$ \\
\hline Per warhead & $2-6 \mathrm{~kg}$ & $10-40 \mathrm{~kg}$ & & \\
\hline Number & 8 & 22 & & \\
\hline Total & & 30 & & $13-92 / 52$ \\
\hline
\end{tabular}

Source: Moon Chang-yul, "North Korea's Nuclear and Missile Threat," The 2016 Summer Seminar, hosted by Korea Association of Military Science, June 23, 2016, Ministry of National Defense Convention Center.

States, Kim Jong-il made every effort to develop North Korea's nuclear program in the 2000s. After Kim Jong-un assumed the position of supreme commander of North Korean People's Army on December 30, 2011, he has been deeply involved in North Korea's nuclear program. Under his rule, North Korea carried out 3 nuclear tests and 32 long-range ballistic missile launches, two times more than that in the Kim Jong-il era. During this period, North Korea also conducted 3 SLBM launch tests and a new model S-300 Multiple Rocket Launcher (MRL) test. Furthermore, North Korea frequently conducts distributed denial of service (DDoS) attacks in order to undermine the ROK administration, broadcasting services, the transportation sector, and financial networks; it has also conducted numerous cyberattacks against cell-phones and Interpark, i.e., Internet shopping malls. In addition, North Korea sporadically sends drones to infiltrate into

Determined to achieve military unification of the

Peninsula, North

Korea has

continually

upgraded its nuclear and missile

programs. the South. All these exemplify North Korea's provocation and even intention to wage war.

Kim Jong-un's military strategy can be inferred from the reinforcement of North Korea's asymmetric combat power and his "Seven Days War Plan," largely verified by the forward movement of North Korean troops in August 20, 2015, fire exchanges due to the incident of two South Korean soldiers maimed by North Korean landmines in the demilitarized zone (DMZ). North Korea has attempted to communize the whole Peninsula by military means with an integrated 
strategy of interdicting augmented deployment of U.S. forces to the Peninsula by preemptive strikes (with nuclear missiles if necessary), launching cyberattacks, and preparing for massive artillery warfare and speedy decisive maneuver warfare, with special operation forces opening the second front. In fact, Kim Jong-un's graduation thesis at Kim Il-sung Military University was entitled "Strategic Concept regarding Employment of Fire Asset," which indicates that he has always been in a position to observe onspot key strategic weapon tests and war-plan implementation exercises. Regardless of any external impediment and constraint, Kim Jong-un has been acting in accordance with the deliberate scenario for a unification war. If conditions allow, he would very likely launch a unification war by surprise attacks with nuclear missiles. In short, North Korea's nuclear program is Kim Jong-un's initiative for neo-fantasy and a core asset for breaking the status quo so as to achieve a unified Korea.

\section{The Need for THAAD Deployment in South Korea}

Given North Korea's accelerating nuclear program, the ROK needs to take firm, proactive strategic measures to protect its people and U.S. forces on the Peninsula against the imminent and grave security threat from North Korea. It is necessary to deploy THAAD in South Korea, for if South Korea and the United States do not take any deterrence-by-denial measures in the face of such threat, the ROK will be practically disarmed and fall victim to nuclear intimidation and - in an even worse case - nuclear bombardment.

Deterrence by punishment can be implemented under a coercive strategy via show of force. ${ }^{3}$ U.S. strategic weapons such as B-2, B-52, F-35, and aircraft carriers, which can be equipped with nuclear missiles, should be deployed to the Korean Peninsula, to exhibit power and prevent North Korea from waging a nuclear missile war. ${ }^{4}$ Also, U.S. forces stationed on the Peninsula are always considered by North Korea as the greatest obstacle in the course of a unification war. If North Korea wages a total war, it would prioritize neutralizing U.S. bases as primary targets. As Table 2 shows, by

${ }^{3}$ Lawrence Freedman, Deterrence: Themes for the 21st Century (Cambridge: Politics Press, 2004), p. 26.

${ }^{4}$ Chung Kyung-young, “The Large-scale Key Resolve/Foal Eagle ROK-U.S. Exercises and Their Implications," RINSA Forum, Korea National Defense University, April, 2016. 


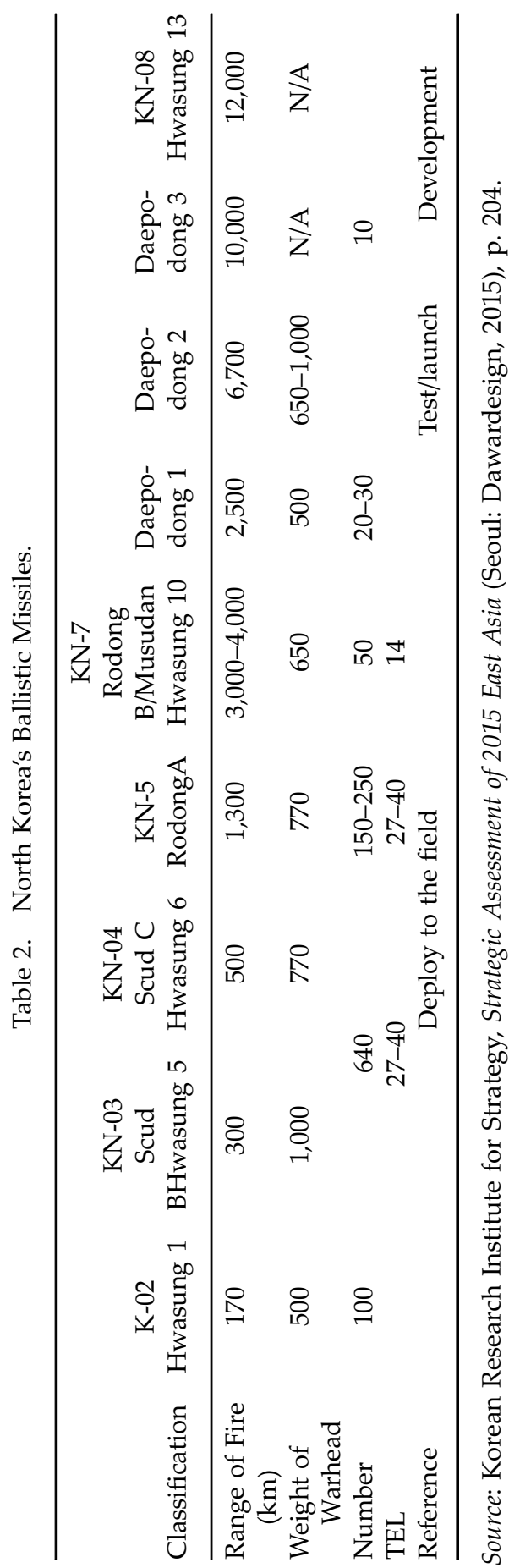


deploying the THAAD system, the ROK-U.S. combined forces could destroy North Korea's nuclear missiles at the terminal stage and protect their critical assets, and then conduct effective counter-offensive operations.

The ROK-U.S. alliance is the backbone of South Korea's national security and also the cornerstone of deterring war and maintaining stability in Northeast Asia. Thanks to this alliance, the ROK has become the world's eleventh-largest economy and sixth-largest exporting country in 2015. When North Korea initiated military provocations including the sinking of the Cheonan and the shelling of Yeonpyung Island in 2010, South Korea could have initiated prompt and massive retaliations if the United States had not urged self-restraint on the South's part. On the one hand, the ROKU.S. alliance has constrained the ROK from initiating any offensive along with the United Nations Command as the key actor of armistice management. On the other hand, while enhancing its alliance with the United States, the ROK cannot underestimate the important role of China regarding sustainable economic development, peace, and unification of the Peninsula. In light of this, South Korea and China have made substantial progress over the past years in promoting their strategic partnership of cooperation. Meanwhile, skepticism also emerged in the United States that the ROK's cozying up to China has weakened ROK-U.S. Relations.

As a matter of fact, the ROK government maintained strategic ambiguity on THAAD deployment at the beginning, symbolized by its announcement of "Three Nos" - no proposal, no consultation, and no decision. It was not until North Korea launched its fourth nuclear test on January 6, 2016 with another long ballistic missile test two days later that the ROK government decided to consult with the United States for deploying the THAAD sys-

South Korea has no choice but to deploy THAAD due to increasing nuclear threat from North Korea. tem. However, considering China's position on this issue, the ROK government has remained prudent during the consultation. It is believed that the June 22 Musudan test demonstrating North Korea's medium-range missile capability served as a decisive factor in South Korea's final decision to deploy the THAAD system.

The Musudan missile was launched 83-degree high in altitude flight, $1413.8 \mathrm{~km}$ elevation and $400 \mathrm{~km}$ forward objective on the East Sea. In the 
July 19 test, the Scud and Rodong missiles dropped at $500 \mathrm{~km}$ and $600 \mathrm{~km}$ on East Sea respectively. If North Korea had switched the vector of missile projection to 80-90 degree to the right, these missiles may have hit ports and air bases along the East and South Sea. With the imminent threat from North Korea, it is inevitable for the ROK to deploy the THAAD system to defend its national security, which is an issue of national survival that is more important than anything. In this sense, South Korea will not give up its military sovereignty under external pressure. As it turned out, public support in South Korea on THAAD deployment rose 6 percent one month after the decision was officially made. ${ }^{5}$

\section{Contending Views on THAAD Deployment}

Although the THAAD system is expected to be deployed in 2017 at Seongju Lotte Golf Course, a decision jointly made by the ROK and the United States on September 30, 2016, some contentious issues need to be addressed here.

To begin with, China perceives the deployment of THAAD in South Korea as a threat to its national security. China insists that the range of detection by AN/TPY-2, the Forward Base Radar, is 1,800-2,000 km, which will be able to conduct surveillance and detection of military activities in inland China. Even with China's ICBM flight over the Korean Peninsula, the Chinese government remains adamant that the THAAD installment on the Peninsula cannot be accepted. According to the Federation of American Scientists, China is sensitive that the X-band radar could detect five ballistic missile units including DF-21 at Dengshahe in Liaoning province. ${ }^{6}$

South Korea fully understands China's security concerns, but considers China's argument and unrelenting opposition inappropriate in terms of truth or fact. Most medium- and high-altitude missiles threatening highvalue targets including U.S. Military bases in South Korea are extensively

5“THAAD Deployment 56\% Pros and 31\% Cons, 6\% Up, Pros within One Month,” Dongahllbo, August 13, 2016. It is noteworthy that the rate for pros in Kyungsang northernprovince where the government planned to deploy THAAD was higher than any other region.

${ }^{6}$ Hans M. Kristensen, "Pentagon Report and Chinese Nuclear Forces," Federal of American Scientists, May 18, 2016, http://fas.org/blogs/security/2016/05/chinareport2016/. 
located near the border between North Korea and China. Approximately 1,000 North Korean missiles are too serious for the existing units to detect, let alone to intercept, to protect South Korea and U.S. forces on the Peninsula. There is no reason for the United States to deploy AN/TPY-2, the Forward Base Radar. Employing the terminal mode radar with an 800-km range of detection, THAAD apparently aims at destroying attacking missiles at the terminal stage.

Indeed, the United States can thoroughly detect China's military activities by the X-band radar already deployed in Japan and Guam, together with its military satellites. In addition, the THAAD system, whose range of fire is $40-150 \mathrm{~km}$, is beyond the capability of ICBM elevation in flight that is above $1,000 \mathrm{~km} .{ }^{7}$ In the meantime, China has already installed and employed the X-band radar with a 5,500-km range of detection in Heilongjiang Province and Fushun that conducts deep surveillance over Japan and the western Pacific. China has also contracted S400 Surface-to-AirMissile (SAM) with Russia whose performance is not inferior to the THAAD system. As China continues to reinforce its surveillance activities, its opposition to THAAD deployment appears unjustifiable because the system is of a purely defensive nature.

Other opponents to the deployment of THAAD contend that South Korea will automatically join the U.S.-led Missile Defense System (MDS) and the ROK-U.S.-Japan trilateral military cooperation to contain China and Russia as their common adversaries. This will force China and Russia - and even North Korea - to take joint counter-actions against the southern bloc. Eventually, the THAAD deployment will break the existing strategic balance and give rise to arms races in Northeast Asia. ${ }^{8}$

Since the Kim Dae-jung administration in the early 2000s, the ROK government has pursued consistent policies that South Korea will not join the MDS - even if the United States deploys the THAAD system on the Peninsula. As South Korean Defense Minister Han Min-koo put it, the

${ }^{7}$ Chung Kyung-young, "Debate on THAAD Deployment and ROK National Security," EAI Institute Working Paper (Seoul: East Asia Institute, 2015), http://www.eai.or.kr/type_k/ panelView.asp?bytag $=$ p\&catcode $=+\& \operatorname{code}=$ korreport\&id $x=14150 \&$ page $=1$.

${ }^{8}$ See, for example, Zhang Zhexin, "Beyond the Strategic Deterrence Narrative: Deploying THAAD May Trigger Immediate Security Crises in Asia," CSIS CogitAsia, March 28, 2016, http://cogitasia.com/beyond-the-strategic-deterrence-narrative-deploying-thaadmay-trigger-immediate-security-crises-in-asia/. 
planned deployment of an advanced U.S. anti-missile system is for selfdefense purpose only and the ROK will not be incorporated into the wider U.S. MDS. These remarks made at the National Assembly policy review session came after speculations that the deployment of THAAD system in South Korea would invariably drag the country into the Washington-led MDS, which was seen by many as a move to isolate China. ${ }^{9}$ As further evidence, the ROK government has refrained from signing a Memorandum of Understanding (MOU) with the U.S. to join the MDS and other joint Research \& Development (R\&D) projects on missile defensive systems. ${ }^{10}$

Deploying THAAD will neither threaten China's and Russia's national security nor harm the regional strategic balance.
As mentioned above, the THAAD system will solely aim at coping with North Korea's nuclear missile threat. The range of detection of the AN/TPY-2 terminal mode radar is $600-800 \mathrm{~km}$, limited to the south of border between China and North Korea. ${ }^{11}$ The THAAD system on the Korean Peninsula will not connect its network with the U.S. regional MDS. In particular, unlike the X-band radar in Japan, the planned THAAD system will not interface with Command and Control, Battle Management and Communication (C2BMC) co-located with Northern Command in the Continental U.S. and Pacific Command in Hawaii. ${ }^{12}$ Similarly, closer ROKU.S.-Japan military cooperation is only targeted at North Korea's nuclear and missile threat, and will not possibly develop into a military alliance against any other country in the foreseeable future. The ROK has long recognized that it should never engage itself in strategic confrontation

9“Local THAAD will not be Incorporated into Wider U.S.-led MD System: Defense Chief," Yonhap July 20, 2016.

${ }^{10}$ Ryu Jae-seung, “THAAD Deployment and Security on the Korean Peninsula," 120th Morning Forum, Korean Institute for Maritime Strategy, October 6, 2016, the War Memorial of Korea.

11 “S.Korea's President Calls for Unity over 'Inevitable' THAAD Deployment Despite Oppositions," Asia-Pacific Daily, July 22, 2016, http://en.apdnews.com/asia-pacific/northeastasia/451995.html.

12“Command and Control, Battle Management, and Communications (C2BMC)," Missile Defense Agency, August 10, 2016, https://www.mda.mil/system/c2bmc.html. 
between blocs, as it will be detrimental to regional stability as well as the peaceful unification of the Korean Peninsula.

There are also opposing groups in South Korea that criticize the government's decision from a utilitarian perspective. If South Korea purchases the THAAD system, they argue, the Korean Air Missile Defense system would be suspended due to dual investment, which means South Korea's self-reliant defense will be farther away and the transition of wartime operational control will not be implemented. ${ }^{13}$ However, the Kill Chain and Korean Air Missile Defense system (KAMD) reflect the Koreanization of weapon systems that will eventually contribute to the transition of wartime operation control. The ROK and the United States have decided to adopt a South Korean condition-based proposal that would have Seoul take wartime control of allied forces when "critical ROK and alliance military capabilities are secured and the security environment on the Korean Peninsula and in the region is conducive to a stable operational control transition." 14

Over the past decades, the ROK has demonstrated its potential in industrialization, democratization and cultural excellence through the "Korean Wave" - even in the turmoil of colonization, the division of the Peninsula, civil war, poverty, and dictatorship, and it will be in a position to exercise wartime operation control over its forces once conditions are met. With time, the new ROK-U.S. combined readiness posture is very hopeful to be led by the ROK forces and supported by the United States. ${ }^{15}$

\section{China's Strategic Miscalculations}

As a key stakeholder in regional peace and stability, China should recognize its strategic errors during the past years on the North Korean nuclear and missile issue, such as dealing with the issue mainly out of concerns about

${ }^{13}$ Chung Kyung-young, Challenge and Reunification Vision of the Korean Peninsula (Seoul: Jisung and Kamsung, 2015), pp. 133-134.

${ }^{14}$ Nick Simeone, "Hagel Details U.S., South Korean Wartime Control Agreement," U.S. Department of Defense, October 23, 2014, http://www.defense.gov/News/Article/Article/603502.

${ }^{15}$ Chung Kyung-young, Korean Centripetal Foreign Security Policy (Seoul: Jisung and Kamsung, 2014), pp. 176-189. 
China-U.S. relations, insisting on maintaining the status quo while doing little when North Korea persistently challenges it, and setting its policy priorities upon inaccurate assessment of regional security dynamics. ${ }^{16}$

In the first place, China has been inclined to evaluate the Korean Peninsula situation from the lens of U.S.-China relations. After North Korea's fourth nuclear test and ballistic missile launch, the Chinese government announced three principles: (a) denuclearization of the Korean Peninsula; (b) safeguarding stability and peace on the Korean Peninsula; and (c) resolving issues through dialogue and negotiation. The Chinese government also proposed a parallel-track approach to realize denuclearization and conclude a peace treaty. However, North Korea holds an opposite position: "In the event of mixing a peace treaty and denuclearization, any one of the issues will never be resolved. This is truth verified by the practice." ${ }^{17}$ Seeking to reach a peace treaty and have the U.S. forces pulled out of the Korean Peninsula, China would like to see diminished U.S. influence in the region. Yet the ROK believes that such a peace treaty could undermine China's principle of safeguarding stability and peace on the Peninsula. Therefore, the ROK and United States do not support the parallel-track approach proposed by China.

Second, there is an enduring contradiction between China's advocacy for maintaining the status quo and North Korea's persistent challenges to it. Chinese President Xi Jinping made it clear in his telephone conversation with South Korean President Park Geun-hye on February 5, 2016 that "there should be no nuclear arsenal on the Korean Peninsula" and that "there should be no war or chaos on the Peninsula." ${ }^{18}$ These statements exemplify China's position of maintaining the status quo on the Peninsula. However, President Xi's "Two No Principles" and Kim Jong-un's pursuit of breaking the status quo collide with each other. As a result, China's policy does not properly reflect the changing reality. Seeking a strategy for maintaining the

${ }^{16}$ Chung Sang-don, “Nature of North Korea's Nuclear Issue and China's Strategic Fallacy," Defense Weekly Forum, Vol. 16-20, No. 1618 (May 2016).

17 "The Chosun Armistice Agreement should be Superseded by a Peace treaty," Rodong Shinmoon, December 15, 2015.

18"Xi Jinping: Chaoxian Bandao Buneng Youhe ye Buneng Shengzhan Shengluan [Korean Peninsular must be Nuclear-free, and Chaos and War are Not Allowed: Xi Jinping]," Sina News, February 6, 2016, http://mil.news.sina.com.cn/china/2016-02-06/doc-ifxpfhzk9011397. shtml. 
status quo, China agrees to join in international sanctions against North Korea under the condition that these measures will not disrupt North Korea's domestic stability. But faced by Kim Jong-un's intransigent attempts to change the status quo, China's lukewarm action cannot serve its policy objectives set by the "Two No Principles" and will eventually delay the resolution of the North Korean nuclear issue, not to mention weaken its leadership in the region.

China's third strategic error comes from its flawed assessment of the regional situation and its policy prioritization. China insists that THAAD deployment in South Korea will jeopardize China's national security and regional stability. But as U.S. Secretary of State John Kerry pointed out, "the only reason for the United States and South Korea to consider deploying the THAAD missile defense system is because of North Korean threats, and the system won't be necessary if the communist nation is denuclearized." ${ }^{19}$ President Park Geun-hye also reiterated many times that "Seoul does not need to deploy THAAD on the Peninsula if North Korea's threats are abolished." ${ }^{20}$ Thus China's error is first browbeating South Korea, then turning away rather than reshaping a new regional order with South Korea for an anticipated future.

\section{Strategies for Tackling North Korea's Nuclear Challenge}

To effectively manage North Korea's nuclear and missile threat and ultimately achieve denuclearization of the Korean Peninsula, three strategic pillars are necessary, namely, the ROK strategy, the ROK-U.S. alliance, and ROK-U.S.-China strategic cooperation.

Undoubtedly, the ROK's strategy will play a primary role in dealing with the North Korean nuclear issue. At present, South Korean forces pursue the Kill Chain, Korean Air Missile Defense (KAMD), and Korean Massive Retaliation Punishment (KMRP) as a strategic tripod to counter North Korea's nuclear and missile threat. The Kill Chain attempts to

19 “Kerry: THAAD not Necessary if N. Korea is Denuclearized," Korean Times, February 23, 2016, http://www.koreatimes.co.kr/www/news/nation/2016/02/485_198836.html.

${ }^{20 " S o u t h ~ K o r e a ' s ~ P a r k ~ G e u n-h y e: ~ T H A A D ~ U n n e c e s s a r y ~ I f ~ N o r t h ~ K o r e a ~ T h r e a t ~ S u b-~}$ sides," UPI, September 2, 2016, http://www.upi.com/South-Koreas-Park-Geun-hye-THAADunnecessary-if-North-Korea-threat-subsides/9561472828749/. 
conduct preemptive strikes against the North Korean nuclear attack capabilities by neutralizing the command and control system for nuclear attacks, the delivery system, warheads, and so on. ${ }^{21}$ The KAMD comprises the early warning system to detect approaching ballistic missiles, the command and control system to conduct instant analysis and give prompt orders for operation, and the intercept system by which Patriot missiles will be launched to intercept approaching missiles at the terminal stage. And KMRP will be employed when detecting clear-cut indicators of North Korea's nuclear missile attacks, which makes it necessary for ROK forces to be equipped with retaliation operation capabilities to partially annihilate Pyongyang with cruise missiles, long and medium surface-to-air missiles, and bunker busters, and to eliminate North Korean war headquarters with such powerful assets as the Special Operation Task Force. ${ }^{22}$

Perhaps the most reliable way to counter North Korea's nuclear threat is to be armed with nuclear weapons. South Korea could develop its own nuclear arsenal to contain the North Korean nuclear horror through Mutual Assurance Destruction. Debate on independent nuclear armament is ongoing in South Korea, with 65.1 percent of the public in support of the idea, and 29.3 percent against it. ${ }^{23}$ As General Vincent K. Brooks, commander of U.S. Forces in South Korea, mentioned at the U.S. Congress nomination hearing on April 19, 2016, "South Korea would have to think about developing its own nuclear weapons for self-defense if the United States removes its 'nuclear umbrella' protection for the Asian ally." ${ }^{24}$ Yet South Korea will certainly face huge obstacles in nuclear development - if it withdrew from the Non-Proliferation Treaty (NPT), the international sanction would have incredible impact on the country's economy, which is 55 times larger than North Korea's (US $\$ 1,470$ billion versus $\$ 26.7$ billion in

${ }^{21}$ Yoon Jung-won, “The ROK Military Security Response Options against North Korea's Nuclear Threat," Summer Academic Conference, Korean Association of International Studies, June 23, 2016, Kangwonn Land Convention Hotel.

22 “The ROK Forces, 'Massive Retaliation \& Punishment in the Event of Indicators of North Korea's Nuclear Attack,"' Donga Ilbo, September 10, 2016.

${ }^{23}$ Munhwa Broadcast System conducted this public opinion survey on September 12-13, 2016, http://vvvvvvvv.tistory.com/1615.

${ }^{24}$ See General Vincent K. Brooks' testimony at a hearing of the U.S. Senate Armed Services Committee on April 19, 2016, http://www.armed-services.senate.gov/imo/media/ doc/Brooks_02-19-16.pdf. 
terms of GDP). In particular, the ROK would have to be prepared for the U.S. revocation of its security commitment to help defend South Korea. Besides, it may generate a Domino Effect on Japan and even Taiwan.

In reality, the ROK-U.S. alliance remains the key to coping with the nuclear and missile threat from North Korea. In the mid-1970s, the U.S. made the ROK abandon its nuclear development and promised to provide the ROK with a nuclear umbrella. In 1978, the ROK and the U.S. agreed at the 11th ROK-U.S. Security Consultative Meeting (SCM) to add specific wording in their joint communique that endorsed the continuing role of "the nuclear umbrella," in addition to enhanced conventional deterrence measures including more joint military exercises between U.S. and South Korean forces. ${ }^{25}$

The U.S. government's Nuclear Posture Review in 2002 put in motion a major change in the U.S. approach to the role of nuclear offensive forces in the deterrent strategy, and presented the blueprint for transforming the U.S. strategic posture. Nevertheless, to meet the U.S. defense goals in the 21st century, ICBMs, SLBMs, bombers and nuclear weapons would continue to play a vital role. ${ }^{26}$ The 2006 reaffirmation appeared in the communiqué, and was made in the context of the North Korean nuclear test on October 9. The statement explicitly mentioned "extended deterrence." In 2010, the Review explicitly strengthened assurance to non-nuclear-weapon states that the U.S. will not use or threaten to use nuclear weapons against them. Confronted with North Korea's intransigent attempts in nuclear development, the ROK-U.S. SCM in 2013 agreed to develop the Tailored Deterrence Strategy (TDS) that aimed at materializing their deterrence with readiness for use. On the 2014 SCM, they signed another agreement on launching the Deterrence Strategy Committee (DSC), which was tasked with developing the allies' anti-missile concept into a concrete operational plan. The ROK-U.S. alliance then focused on developing the allies' proactive defense concept named the " $4 \mathrm{D}$ " Concept - "Detect, Defense,

${ }^{25}$ Andrew O'Neil, Asia, The US and Extended Nuclear Deterrence: Atomic Umbrellas in the Twenty-first Century (London and New York: Routledge, 2013), pp. 62; “Korea Is And Will Continue to Be under the U.S. Nuclear Umbrella," Joint Communiqué, Eleventh Annual US-ROK Security Consultative Meeting, July 27, 1978, San Diego.

${ }^{26}$ U.S. Department of Defense, Nuclear Posture Review, January 8, 2002. 
Disrupt and Destroy," representing the four major steps to handle Pyongyang's potential nuclear and missile attacks. ${ }^{27}$

Nevertheless, this author does not argue for the ROK's nuclear armament, but that tactical nuclear warheads should be redeployed to the Korean theater. The United States possesses 760 tactical warheads in total, 200 of which (aircraft-deliverable) are deployed in Germany, Italy, Turkey, Netherlands, and Belgium, among other member states of the North Atlantic Treaty Organization (NATO), 300 (aircraft-deliverable) are dispersed in the United States, and the other 260 can be delivered by maritime Tomahawk missiles. ${ }^{28}$ Since the Joint Communique on the Denuclearization on the Korean Peninsula agreed by the two Koreas in 1992 is no longer in effect due to North Korea's nuclear arsenal, it would make strategic sense for the United States to redeploy some of the missile-deliverable warheads to South Korea, so as to generate the biggest physical and psychological effect on North Korea's deliberations. In so doing, it is important that Presidents of the ROK and the United States exercise joint authority over the nuclear warheads; also, if North Korea abandons its nuclear program, these warheads should be withdrawn immediately.

ROK-U.S.-China

strategic cooperation

is essential to

tackling North

Korea's nuclear

challenge.

Last but not least, ROK-U.S.-China strategic cooperation will be essential to preventing any potential nuclear warfare and maintaining peace and stability on the Korean Peninsula. All countries in Northeast Asia, in particular the ROK, the United States, and China, perceive the North Korean nuclear program as a serious threat to regional peace and stability. That is why they should take cooperative security measures to deal with North Korea's nuclear challenge. The concept of cooperative security derives from common security, a principle for comprehensive efforts to minimize risks of war. The concept is based on the notion of "security

27 “Korea, U.S. to Devise Plan to Negate N.K. launchers,” Korea Herald, April 16, 2016, http://www.koreaherald.com/view.php?ud=20150416000945.

${ }^{28}$ Tom Nichols, Douglas Stuart, and Jeffrey D. McCausland, eds., Tactical Nuclear Weapons and NATO, GlobalSecurity.org, April 2012, http://www.globalsecurity.org/wmd/library/report/2012/ssi_nichols-stuart-mccausland.pdf. 
with" as opposed to "security against" an adversary, real or potential. Meanwhile, common security advocates combining the "security with" notion with the alliance systems, a product of insecurity triggered by the security dilemma and arms races. ${ }^{29}$ In order to facilitate peace, disarmament, and arms control, a proactive strategy of all countries concerned is absolutely necessary.

China's policy toward North Korea can critically determine the fate of the region. It is time China worked more closely with the United States and South Korea to establish a nuclear-free and unified Korean Peninsula. If they can jointly pressure North Korea to abandon its nuclear program and mitigate its threatening military posture, a stable and prosperous Northeast Asia led by China and the United States with its allies can be guaranteed. However, if China declines to cooperate and North Korea continues to refuse to negotiate, South Korea will have no choice but to work with the United States and Japan to "consider more assertive military and political actions, including those that directly threaten the existence of the North Korean regime and its nuclear and missile capabilities." ${ }^{30}$ If the North Korean nuclear issue continues to worsen, military confrontation and risks of war are bound to increase on the Peninsula, which will ultimately harm China's national interests as well.

\section{Conclusion and Policy Recommendations}

Considering North Korea's direct and grave nuclear and missile threat and its unification war strategy, the THAAD system needs to be deployed in South Korea to achieve deterrence by denial and protect the South Korean people and the U.S. forces. It is generally agreed that North Korea has been determined to develop its nuclear arsenal so as to achieve a unified nuclear Korea, thus the three strategic pillars - the ROK's strategy, the ROKU.S. alliance, and ROK-U.S.-China strategic cooperation - are indispensable in coping with Kim Jong-un's strategic fantasy. Closer cooperation

${ }^{29}$ Independent Commission on Disarmament and Security Issues, Common Security: A Blueprint for Survival (New York: Simon and Schuster, 1982), p. 7.

${ }^{30}$ CFR Independent Task Force, A Sharper Choice on North Korea: Engaging China for a Stable Northeast Asia (New York: Council on Foreign Relations, September 2016), http://i.cfr. org/content/publications/attachments/TFR74_North\%20Korea.pdf. 
among the ROK, the U.S. and China is of particular significance to promoting peace and stability on the Korean Peninsula and in Northeast Asia at large.

This author would like to offer some specific policy recommendations on enhancing regional cooperation on the North Korean nuclear issue. First, all countries concerned should propose restructured negotiations that will incentivize Pyongyang to negotiate on important issues, culminating in complete and verifiable denuclearization and a treaty that will end the tensions on the Peninsula. The ROK, the United States, and China should adopt a more proactive engagement policy in order to encourage the North Korean people and elites to adopt denuclearization in the event of Kim Jong-un's continuing denial of denuclearization. In addition, to facilitate North Korea's transformation, more measures should be taken to integrate information liberalization, humanitarian support (such as providing aid for the victims from the Tumen River floods), intervention in human rights issues, and, in the worst case, support for the substitute power. Since North Korea has never yielded under UN sanctions and has been constantly challenging the UN Charter, the UNSC should consider some military options, such as surgical strikes on North Korea's nuclear test tunnels or missile production factories, in the event of any further nuclear test and ICBM launch by North Korea.

Second, the ROK-U.S.-China annual meeting on North Korea Intelligence Assessment should be institutionalized. Strategic mistrust among the three countries comes in part from their huge perception gap of North Korea's national strategy and military power. As a signatory to the armistice agreement, China should be aware of the possibility of a joint ROK-U.S. counter-military provocation plan, which allows the ROK forces to promptly retaliate against North Korea's military provocations in self-defense and the United States to massively deploy strategic assets in the Peninsula in order to prevent the escalation of hostility.

Third, the U.S. government should seriously reconsider the redeployment of tactical nuclear warheads to South Korea, in order to quell the rising public opinion on the need for ROK nuclear armament and ensure the effectiveness of the U.S. commitment on extended deterrence. The new ROK-U.S. combined readiness posture should be led by the ROK forces, while the United States should delegate authority to the ROK in order to exercise wartime operation control over its forces in accordance with the 
conditions-based transition of wartime control. In the meantime, the ROK government should make it clear that the country does not seek to join, nor will it be incorporated into, the missile defense system led by the United States, and that the tactical nuclear warheads should be immediately withdrawn if North Korea is to abandon its nuclear arsenal.

Finally, the United States and China should cooperate and consult with the ROK in order to take the lead in achieving a norm-oriented, nuclearfree, and unified Korea. The three countries should work more closely together on both strategic and operational levels to make sure that North Korea will never succeed in its attempts to unify the Peninsula by surprise attacks with nuclear missiles. 